\title{
EDUCATIONAL CHANGE: A CASE FOR A 'PEDAGOGY OF COMPASSION'
}

\author{
Saloshna Vandeyar \\ University of Pretoria \\ Email: Saloshna.Vandeyar@up.ac.za
}

\section{Ronel Swart}

University of Pretoria

Email: Ronel.Swart@up.ac.za

\section{ABSTRACT}

This paper sets out to advance the concept of an 'epistemology of compassion' first proposed by Vandeyar $(2013 ; 2016)$. Utilising a single embedded case study and the theoretical mooring of post-conflict pedagogy this paper attempts to find links between Jansen's perceptions of a post-conflict pedagogy and Freirean pedagogy and to argue a case for a 'pedagogy of compassion' as a possible approach to addressing and transforming education in post-apartheid South Africa. Data capture comprised a mix of semi-structured interviews, observations and field notes. Data was analysed by means of the content analysis method. Findings were threefold. First, the implementation of a 'pedagogy of compassion' enabled the teacher to dismantle polarised thinking and to shatter the polite silence of postapartheid South African society. Second, teachers not only need to be able to raise the critical consciousness of learners but they need to adopt an 'epistemology of compassion' in order to enable learners to become active critical citizens, imbued with a sense of common humanity and compassion. And third, becoming an agent of transformative change may challenge the very premise of teachers' identities and practices, but by empowering the learner to exert influence on her world, the teacher is in turn also changed and empowered.

Keywords: pedagogy of compassion; social cohesion; teacher; post-conflict pedagogy; transformative intellectual; classroom; diversity teaching

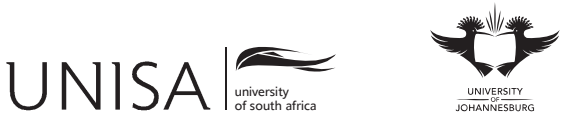




\section{INTRODUCTION AND BACKGROUND CONTEXT}

Education in South Africa remains a contentious issue. Evidence of the controversy related to education can be seen from recent press reports and YouTube video clips (e.g. learners assaulting a teacher with a broom and shooting a teacher) (Makhubu 2013, 1). One newspaper headline reads, 'Three pupils held over unlicensed firearms: police chased suspects from school' (Seleka 2013, 6). Another headline reads, 'Gang war at city school: pupil's ear cut off; other had sharp object in back' (Makhubu 2013, 1). Teachers that are guilty of gross misconduct have also been exposed: 'Teacher suspended for money blunders' (Fredericks 2013, 12), 'Rapist teachers shame SA' (Otto 2013, 6) and 'Burning schools undermines right to basic education' (Khoza 2016).

Jansen (2012) in a public address predicted that the South African education system is a threat to democracy: 'Our democracy will implode if we do not attend to the education system'. He claimed that a poor education system breeds social ills such as violence and crime. 'Teachers sleep with pupils, there is rape, drugs and pregnancies right in our schools. The violence we witness daily is because of the failure of the education system' (Jansen 2012). Four years later, the abovementioned newspaper headlines bear witness to this prediction.

Segregated education was the defining character of the apartheid era. Desegregation was a premise and promise of the newfound democracy. Discriminatory laws and rules were abolished. Racialised history in school texts and explicit and implicit biases in other instructional materials were eradicated. But was this sufficient? How were former white schools to become institutions that welcomed mass education and black students? Who was to help teachers learn that what they regarded as human nature was neither innate nor absolute? How could schools be desegregated amidst persisting residential segregation? What forms would transformation take as those who resisted desegregation used commitments to local control, to home language education, and to reconciliation to protect their privilege? (Samoff 2008, 12). A pedagogy of compassion plays a key role in both preventing conflict and rebuilding a fractured post-apartheid South African society. It harbours the potential to restore stability and peace in South Africa, thus attracting potential investors to South Africa.

Given the bleak picture of the South African education system, we could not help but heed Jansen's (2012) call for a post-conflict pedagogy for South Africa. Jansen postulates that we have moved past critical theory (Jansen 2009, 150-151). Similarly, Freire's view of the teacher as a transformative intellectual evolved beyond the narrow confines of critical theory. The purpose of this paper is to explore what constitutes a post-conflict pedagogy and how Freire's work in post-conflict Brazil and his call for teachers to act as transformative intellectuals could contribute towards a pedagogy of compassion in South Africa and elsewhere in the world. This is the gap that we propose to address in this paper. Accordingly, this paper attempts to argue a case for a pedagogy of compassion as a possible approach to addressing and transforming education in South 
Africa and utilises a single embedded case study to show how a teacher can become an agent of transformative change.

The definition of a 'transformative intellectual' viewed through the lens of critical theory emphasises the pertinent role that the teacher plays in the mediation of learning and the selection of content, themes and learning support materials (Giroux 1983; Habermas 1981). This definition aligns with Freire's (1970, xii) early work, namely Pedagogy of the Oppressed, in which he argued that teachers need to be 'transformative intellectuals' who engage in social change and are able to make the pedagogical more political and the political more pedagogical. Teachers need to expose the reproductive role of education and to instil faith in students to overcome the economic, social and political struggle and to educate and humanise themselves as part of the struggle (Fien 1993, 17). It is thus imperative that teachers create opportunities for students to participate in the learning process by making knowledge problematic and making the struggle for a better world a conscious educational goal (Fien 1993, 17).

Freire emphasised the attributes required of the teacher as a transformative intellectual to facilitate learning successfully, namely, humility, lovingness, courage, tolerance, decisiveness, security, patience and the joy of living (Freire 1998, 40-42). These indispensable qualities are not ranked according to importance, as all are necessary. However, we will argue that lovingness, a passion for learners, an 'epistemology of compassion' (Vandeyar 2013) and the act of teaching and learning are required if the teacher wishes actively to involve learners in the learning process and to foster social cohesion. For the purpose of this article we find the definition offered by the Organisation of Economic and Cooperative Development (OECD 2011) most appropriate. Social cohesion refers to a cohesive society that works toward the well-being of all its members, fights exclusion and marginalisation, creates a sense of belonging, promotes trust, and offers its members the opportunity of upward mobility. Learning is not only about the content but is also foremost about the relationship that is forged between the learner, the teacher and the learning experience. In order to understand the role of the teacher as a 'transformative intellectual' one has to understand the constraints and possibilities of the curriculum and to begin to analyse and evaluate the space available for the teacher to be a transformative intellectual (Fien 1993, 17; Giroux 1983).

The argument is presented as follows. We briefly sketch the background context to situate the identified intellectual puzzle. We then present a review of the literature that attempts to explore the nature of education based on critical theory and criticisms levelled against this theory, and the capacity of the Freirean version of critical pedagogy to inform the role of the teacher as transformative intellectual in a post-conflict context. This is followed by a brief exposition of the theoretical framework. The paper concludes with a discussion and analysis of findings and unpacks how a teacher can become an agent of transformative change in post-apartheid South African classrooms. 


\section{EXPLORING THE TERRAIN}

\section{Critical Theory}

Critical theory has evolved to become 'a crucial body of scholarship in education that offers a lens for understanding the role of schools in perpetuating and subverting race, class and gender interests of state and society' (Jansen 2009, 150). The role of critical theory in conflict societies has been acknowledged, but researchers have begun to question its influence or use in post-conflict societies.

Numerous criticisms have been levelled against critical theory, namely, it is abstract and prescriptive and threatens to impose a new and oppressive orthodoxy (Maddock 1999, 59; Tubbs 1996), it is idealist, liberal and practises 'revisionist liberalism' (Abrahams 2005, 16) and it has limitations (Ellsworth 1989; Elliot 2005). Most notably are the three points of critique offered by Jansen $(2009,150-152)$, namely, 'critical theory views education from the premise of social justice and thereby implies an unequal world...the world is taken as torn among rival groups (150); it promises ways of solving injustice that are not very achievable in practice; and, it has not been tested in the context of post-conflict situations where martyrological memories are in contention'. If the goal of critical theory education is to free the oppressed, it therefore sides with the oppressed against the oppressor.

Further, Jansen $(2009,151)$ argues that although critical theory pays lip service to the dialogic nature of education it does not empower the teacher to deal with the deeply complex challenges faced in post-conflict classrooms. Learners come to class with knowledge from their own experience or received from the primary agents in their lives and often have deeply divided opinions. It may be that the teacher wishing to act as an agent of critical theory will only alienate learners from each other as critical theory in its more radical form divides the world. Learners come to class as bearers of received knowledge and they do not have one story from the past, a common understanding of the present or a similar future goal (Jansen 2009, 152).

Our shifting understanding of the usefulness of critical theory in post-apartheid South Africa was further influenced by Elliott (2005) who postulates that critical theory, while being theoretically fruitful, is less effective in shaping critical praxis. He further argues that critical social theory helps in defining issues and contexts in which there is a lack of social justice but does not offer a pragmatic modus operandi and has taken researchers down a practical cul-de-sac (Elliot 2005). Hadfield (2012) counters this by stating that the role of critical social theory is not to directly inform practice but rather to identify and describe contexts and processes that create and maintain equality. Our initial research followed this way of thinking and we found the ideas of critical social theory exciting and informative. Challenges encountering South African education, however, have forced us to look at the praxis. What we now need is a plan of action to execute the praxis. 


\section{Freirean pedagogy}

Freire designed and practised a new interpretation of critical education, which was distinct from the usual mode of knowledge transmission. He moved from social critique to critical pedagogy as a result of his experiences of the oppression of the education system in Brazil. He insisted that education is always a political act and that educators have to make political choices because it is impossible to remain neutral in education (Palmer 2001, 129).

The premise from which any discussion on Freirean critical education departs is that it is essentially a set of relations where the teacher and learner are in a partnership and knowledge is constructed through dialogue. The teacher and learner are involved in a respectful relationship in which they think and reason with each other (Gravett 2001,35 ). Our point of departure is that the dialogic nature of this relationship is the true empowerment of the individual which in turn leads to transformation. According to Freire (1998, 40-43), a progressive teacher is one who acts as a transformative intellectual and possesses the attributes of humility, love, courage, tolerance, decisiveness, security, patience and the joy of living in order to facilitate learning successfully. Freire (1985, 106) views teaching and learning as dialogic in nature and understands conscientisation as the process by which human beings participate critically in a transforming act.

One of the important points in conscientization is to provoke recognition of the world, not as a 'given' world, but as a world dynamically 'in the making'. (Freire 1985, 106)

Freire's pedagogy of knowing essentially involves individuals naming their world and the renaming of the world appears to the namers as a problem (Sanzerbacher 1991, 109). Learning is posed as a problem which the learners and the teacher have to solve together. The communication between the teacher and the student in the Freirean paradigm of education is in the form of a dialogue or dialogic teaching. The learner is empowered because she knows that she has a voice and can exercise her voice. For the learner being conscious means the following: 'It pertains to beings that not only know, but they know that they know' (Freire \& Macedo 1998, 127). This implies that learners have the ability to become the subjects of their own knowing as opposed to individuals who passively ingest and accept the teacher's ideology (Sanzerbacher 1991, 112).

Human values are the pivotal point around which teaching and learning revolve in critical education. This emphatically humanist orientation has often been missed by those who have taken up critical education. If every teacher loves the very act of teaching then we are fulfilling Freire's dream of teaching that emphasises human values. Throughout his life Freire believed that every teacher should have a passion for teaching (Darder 2002, 92):

I understand the process of teaching as an act of love. I mean, it is not an act of love in the formal sense, and never in the bureaucratic sense. It is an act of love as an expression of good care, a need to love, first of all, what you do. Can you imagine how painful it is to do anything without passion, to do everything mechanically? 
In the Freirean classroom teachers realise that they don't have all the answers. 'No one knows it all; no one is ignorant of everything' (Freire 1998, 39; Sanzerbacher 1991, 109). This is what Freire sees as true humility, which is one of the qualities that he views as indispensable for a progressive and humanist teacher. Knowledge is not delivered top down in the Freirean view on education. Learners are not empty vessels into which knowledge is deposited, where the teacher is regarded as the only source of knowledge, the transmitter of factual knowledge and the gatekeeper of facts. Together the teacher and learner construct knowledge; together they name the world (Sanzerbacher 1991, 109). Learners are actively involved in learning and developing their own knowledge with the guidance of the teacher. 'Whoever teaches learns in the act of teaching, and whoever learns teaches in the act of learning' (Freire 1998, 31). Relations between teachers and students are fluid and equitable (Ladson-Billings 1995,163). Learners and teachers mutually reflect on knowledge, skills and attitudes acquired or developed during the learning experience. An empowering teacher does not talk knowledge at students but talks with them (Shor 1992, 85).

A progressive teacher should ensure that learning is relevant to the world of the learner, that inter-personal communication is built on respect, that learners take responsibility for their own learning by applying critical thought, that there is decisiveness on the part of the teacher, that humanist values are held in high esteem, that a dialectical tension between patience and impatience is maintained, and that there is a joy of living (Freire 1998, 40-42). The enthusiasm and passion that a teacher possesses for learning, teaching and above all the learner, is contagious. In every way critical pedagogy can be referred to as a pedagogy of love. Without love teachers are empty vessels and have nothing to teach and lack the moral and emotional starting point for critical pedagogy (Freire 1998, 40-42). This implies that the teacher should like the people she teaches, otherwise the teacher will be unable to facilitate empowering pedagogy - hence his concept of love.

Our response to the use of critical education in a post-conflict society is as follows: First, we agree that philosophies of critical education have been best applied at times of resistance. In Pedagogy of Hope Freire revisits Pedagogy of the Oppressed and evolves his ideas on education for political reasons to what can be termed critical education for a post-conflict state. Second, we are in consensus with Elliot (2005) that rather than arriving at a single truth to inform pedagogy, we should work towards a 'fusion of horizons' through a form of consensus-making in order to bring together different views and notions of worthwhile change. However, we want to argue that Freire's view of education goes beyond that of the cultural productive function of the school and offers a much more humanist approach to education. It is this humanist aspect of Freire's pedagogy that lends it useful as a construct for a 'pedagogy of compassion'.

In order to define concepts and to indicate the limitations or parameters of the use of these concepts in this paper the authors hold the view that Freire, Jansen and others' criticism is lodged at the use of critical theory as developed by the Frankfurt School of Social Research. 
The authors' understanding is that critical education is a more inclusive term that includes critical pedagogy but the two terms are used interchangeably in the literature and in this paper.

The new version of critical pedagogy that was developed by Freire is referred to as Freirean pedagogy. Jansen elaborates on this and develops critical pedagogy to become the premise of post-conflict pedagogy. Freire did not want his ideas to simply become a recipe for others to follow, he wanted to show children how to think and in this way challenge the banality of ideological and cultural oppression (Palmer 2001, 182). His vision was that scholars, teachers and learners would apply his ideas in context. Therefore, this paper attempts to link Freirean pedagogy and Jansen's post-conflict pedagogy to a 'pedagogy of compassion' in post-apartheid South Africa.

\section{THEORETICAL MOORINGS: POST-CONFLICT PEDAGOGY}

Jansen's stance on a post-conflict pedagogy can be seen as 'an epistemology of empathy that takes seriously the experiences of both the victims and the perpetrators of apartheid and proposes a post-conflict pedagogy of reconciliation' (Maodzwa-Taruvinge \& Cross 2012 , 126). Jansen $(2009,153)$ identifies three elements of a post-conflict pedagogy, i.e. the disruption of received knowledge, the significance of pedagogic dissonance and the importance of hope.

\section{Disruption of received knowledge}

Educational settings are almost genetically stereotyped (Keet, Zinn \& Porteurs 2009, $110)$ and for this reason Jansen $(2009,153)$ calls for the disruption of knowledge so that all South Africans can confront each other with their respective memories of trauma, tragedies and triumph in the classroom. According to Jansen (2009) polite silences and hidden resentments should be exposed, indirect knowledge should be made explicit and its potential and real harm discussed openly. Dialogue between 'opposing parties' should be encouraged as conflict promotes engagement. Furthermore, Jansen (2009, 153) claims that in order to disrupt knowledge a relational pedagogy is essential.

\section{The significance of pedagogic dissonance}

Jansen $(2009,154)$ claims that dissonance happens when one's stereotypes are shattered. This does not happen overnight. 'One incident of pedagogic dissonance does not of course lead to personal change, but it can begin to erode sure knowledge' (Jansen 2009, 154). Linked to the notion of pedagogic dissonance as argued by Jansen, is the work of Zembylas (2010) which emphasises the proactive and transformative potential of discomfort. Zembylas $(2010,703)$ argues that teachers experience immense discomfort when having to confront growing diversity and multiculturalism. Drawing on Foucault (1994) who introduced an ethic of discomfort, he claims, 
An ethic of discomfort, therefore, invites teachers and students to critique their deeply held assumptions about themselves and others by positioning themselves as witnesses (as opposed to spectators) to social injustices and structurally-limiting practices such that they see and act as ambiguous rather than dualistic subjects (e.g. 'us' and 'them'). (Boler \& Zembylas 2003)

Freire $(1992,95)$ claims that teachers should have a critical democratic outlook on the prescribed content and never allow themselves to succumb to the naïve temptation to look on content as something magical. If teachers treat content as neutral, thereby ignoring what Jansen calls pedagogic dissonance, then the content has power and the teacher can only deposit it in learners and it loses its power to effect the desired change. What is required is 'knowledge of living experience' (Freire 1992, 57).

\section{The importance of hope}

'A post-conflict pedagogy is founded on hope' (Jansen 2009, 154). Freire $(1992,77)$ claims that there is no change without a dream and there is no dream without hope. The hope that Jansen and Freire refer to is achievable in praxis. It is insufficient to just pronounce hope, it should be acted upon. There is no room for utopia in post-conflict pedagogy. In a post-conflict society the former oppressor and the oppressed do not get caught up in a blaming game. Jansen $(2009,154)$ refers to post-conflict pedagogy as follows: 'This kind of critical pedagogy recognizes the power and the pain at play in school and society, and their effects on young people, and then asks "how" things could be better'. Post-conflict pedagogy needs to focus on doing what is right. Similarly, Freire argues that as an individual and as a class, the oppressor can neither liberate nor be liberated. This is why, through self-liberation, in and through the needed just struggle, the oppressed, as an individual and as a class, liberates the oppressor, by the simple act of forbidding him or her to keep on oppressing. 'The liberation of individuals acquires profound meaning only when the transformation of society is achieved' (Freire 1992, 85). The dream becomes a need, a necessity.

\section{RESEARCH STRATEGY}

The meta-theoretical paradigm utilised in this study was that of social constructivism (Guba \& Lincoln 1994). The social constructivist epistemological paradigm advocates that reality exists through people's subjective social experiences of the world. In this study a social constructivist paradigm afforded us the opportunity to interpret a teacher's perspectives on pedagogical practice. The methodological paradigm employed a qualitative single embedded case study (Yin 2013) and narrative inquiry (Clandinin \& Connelly 2000). Narrative inquiry is a way of understanding and inquiring into experience through 'collaboration between researcher and participants, over time, in a place or series of places, and in social interaction with milieus' (Clandinin \& Connelly 2000, 20). Data collection involved a mix of semi-structured interviews, observations, 
field notes and a researcher journal. The examples below predominantly report on data obtained from semi-structured interviews and observations as field notes.

This paper examined data from a larger study that set out to investigate 'best practice' in desegregated South African classrooms. We report on the data of one teacher as an illustrative case study of a 'transformative intellectual' in dialogue with her class on diversity and transformation matters in this paper. Observation was the main data gathering technique used in this study. Observations were conducted in 2012. The researcher observed the teacher over a three-week period. Observed lessons were videotaped and interviews were audiotaped and transcribed. However, it must be noted that there are advantages and limitations of intensive observations at a single school. The advantages of such a technique is that it provides a lens into the 'lived experiences' of classroom life over a period of time that allows for in-depth study and creates the opportunity for patterns (if any) to emerge. The limitation is that observations of a single teacher at one school could be seen as instructive and illustrative, and not as representative of all schools. Semi-structured interviews were conducted with Mrs Steyn during the three-week period of observations. In order to get a better feel for the learning environment, various field notes were made, based on informal observations of classrooms. Attention was also given to the physical atmosphere of the classroom, which included observations of artifacts such as paintings, décor, photographs, portraits and school magazines.

Data was analysed utilising the content analysis method (Mayring 2000; Sandelowski 2000). Codes were generated from the data and continuously modified by the researchers' treatment of the data 'to accommodate new data and new insights about those data' (Sandelowski 2000, 338). Permission to conduct this study was granted by the respective provincial department. This research study received ethics approval from the institutional Ethics Committee at which we are based. The participant was given a pseudonym to fulfil the criteria for anonymity and confidentiality.

\section{FINDINGS: PORTRAIT OF A 'TRANSFORMATIVE INTELLECTUAL'}

We present findings in the form of two illustrative classroom vignettes.

Mrs Steyn, the Grade 5 teacher at Equity Primary, was a white female in her late thirties who taught Arts and Culture, Life Orientation and Mathematics. She completed her schooling and training as a teacher at Afrikaans-medium educational institutions. She has been teaching at Equity Primary school, a former Afrikaans-medium school situated in a former low-middle class white suburb, for the past 18 years. Her initial years of teaching occurred in the previous educational dispensation and she thus taught exclusively to white Afrikaans-speaking students. With the advent of democracy the demographics of students radically changed at the school. Her classrooms comprised 40 
learners. These learners were diverse in terms of race, gender, culture, ethnic groupings, language and socio-economic status.

I have more than eleven cultural groups in my class; more than eight religious groups and of course, two genders. My children also vary in social economic status. They fill me with a most beautiful variety of multicultural love, humor, religions and they make me the richest person in the world.

One could argue that Mrs Steyn is making use of proxies, such as 'cultural groups' to euphemise the use of problematic terms such as 'racial groups'. As a shortcoming, maybe an opportunity for probing Mrs Steyn's use of the above-mentioned proxies was lost during the interview session. However, the fact that we had come across a teacher who really stood out from the majority of teachers who saw all learners as 'the same', a teacher who not only acknowledged difference but also utilised it as an asset in her practice, at that moment did not warrant an interrogation of her use of proxies.

Mrs Steyn took much pride in the appearance of her classroom. The climate of the classroom was inviting, welcoming and stimulating. Every available space in the classroom was filled with diverse cultural posters, pictures, artefacts, fabrics and sculptures that proudly boasted the 'rainbow nation' of South Africa. The walls of the classroom were bright green in colour and were adorned with learners' projects, posters and cultural artefacts that were representative of the class of diverse learners. Artistic drawings of learners, depicting the variety of cultural backgrounds, were draped above and across the classroom. Books were neatly stacked on three racks that projected from the wall on the front left-hand corner of the classroom. Plants and teddy bears that hugged each other were strategically perched on the book racks and windowsills around the classrooms. Proudly displayed on top of the steel cabinet at the front right side of the classroom was the assagai (spear) and shield of Zulu origin. Juxtaposed against this was a minature model of the ox-wagon of Afrikaner origin. Class rules were pinned up on the cupboard. It would seem that in terms of first order changes, Mrs Steyn went to great lengths to create a culture of inclusivity and a sense of belonging for all her learners. Instead of just replacing one culture with another or retaining the hegemonic culture (Afrikaans) of the school, she chose to affirm all cultures and in so doing embraced the 'rainbow nation'. From our observations of the above-mentioned description of Mrs Steyn's classroom it was obvious that she made a concerted attempt at inclusivity through the culturally diverse artefacts that adorned her classroom. In this regard her selection of artefacts was not subjected to interrogation.

\section{Vignette 1}

This was an Arts and Culture lesson in a Grade 5 class. Mrs Steyn was teaching the concept of racism. She had asked each learner to bring one fruit to class. The class comprised 40 learners. The class was divided into eight groups, each group comprised 
five learners. Learners were seated in multicultural groups. Noise centred around activity and groupwork. Utensils were provided for each group to begin making a fruit salad.

Mrs Steyn taught the concept of racism in a real-life and fun way. The lesson commenced with the sequencing of events that related to the life-world of her learners. When you wake up in the morning you bathe, dress, make up your bed, eat breakfast and then come to school. This illustrated sequence then brought in the idea that each person's sequence will be different. Subsequently she introduced the concept of sameness by emphasising that if you do the same things every day it will become very boring; similarly if you eat only one type of fruit every day and no other fruit, 'Will the banana get boring? Will the apple get boring? Will the pears get boring? Will the watermelon get boring?'. She then emphasised that we need variety and difference in our lives and introduced the concept of the fruit salad as a metaphor to teach the concept of racism. She taught the complex and dynamic concept of racism to Grade 5 learners by utilising the simple method of making a fruit salad. She not only acknowledged differences but more importantly utilised it as an asset.

She was fully aware of and constantly alert to the dynamics at play in diversity education, for example gender, socio-economic status and race. A boy in one of the groups gave a banana to one of the girls in his group and told her to peel it. Mrs Steyn immediately picked up on gender bias and reacted in the following way: 'Typical man, gives the banana to the woman to peel. Doesn't your father help in the kitchen? Please take that banana back and make sure you peel it'.

She was also acutely aware of differences in the socio-economic status of her learners and promoted an ethos of sharing among them. She encouraged sharing of items within and across groups in a good way without making any of her learners feel uncomfortable. Some groups had less variety in terms of the fruit that each learner within the group had brought to class. She suggested that groups swop fruit to ensure that they had more variety in making the fruit salad. In so doing she attempted to foster a culture of sharing and cooperation among her learners.

She was alert to race issues as well. A white boy seized an opportunity to move away from a black learner by going to another group and sitting next to another white boy. Mrs Steyn in a very professional manner and without much fuss made it clear that learner shifts were unacceptable and calmly requested that the learner 'swop back please', to which the learner quietly acceded. She then used this incident to consolidate the lesson on racism by explaining to the learner why his actions were problematic. The following conversation ensued:

Mrs Steyn: Pieter why did you move from your group?

Pieter: Cos mam, I wanted to sit next to my friend Altus.

Mrs Steyn: Is Sipho not your friend?

Pieter: Sipho is not my friend.

Mrs Steyn: Why is Sipho not your friend? 
Pieter: Cos, mam he does not live where I live and I don't play with him at home after school.

Mrs Steyn: Is that the only reason you moved Pieter?

Pieter: Yes, mam.

Mrs Steyn: Class why do you think Pieter moved from his group?

A short silence ensued and then one of the learners mumbled 'because Sipho is a black boy'. Mrs Steyn, drawing on Jean Elliot's 'Blue Eyes/ Brown Eyes' exercise, seized this opportune moment to teach about racism by means of experiential learning. She quickly divided the class according to shoe size and made all students who wore a size 1 shoe superior to the others by giving them preferencial treatment. It so happened that Pieter fell into the 'inferior' group and was made to experience prejudice first-hand. She literally put the students in the shoes of the 'other'. She then consolidated the lesson by asking students from both the 'superior' and 'inferior' group how they felt in these designated groups. In so doing some students who were prejudiced against in terms of skin colour experienced what it was like to be in a 'superior' group and vice versa.

Mrs Steyn: Class do you think it is fair to treat people differently because of the size of there feet?

Class: No mam.

Mrs Steyn: Why is it not fair?

Tanya (a white learner giggles): Because we can't control the size of our feet...we born with it.

Mrs Steyn: Then do you think we can control the colour of our skin?

Class: No mam.

Mrs Steyn: Is it fair to treat people differently because of the colour of their skin or because they look different from us?

Class: No mam.

Mrs Steyn: I want you all to remember this exercise, the next time you want to treat people differently because of the colour of their skin.

Given the South African context, it should be noted that many teachers in the broader study were silent, ignored or brushed racist issues aside in class. In contrast Mrs Steyn tackled it. Within the new South African education context of diverse classrooms, it may be that Mrs Steyn did not as yet craft a teaching pedagogy to interrogate what may be perceived as racism. She nevertheless challenged the learners' actions as sensitively and as best as she knew how. This kind of critical pedagogy recognises the power and pain at play in school and society, and their effects on young people, and then asks 'how things could be better'.

\section{Vignette 2}

This was a Life Orientation lesson based on emotions and love. The lesson commenced with Mrs Steyn congratulating three learners who had celebrated their birthdays during 
the week. She took time to make them feel special and reminded them to collect a KFC voucher from her at the end of the lesson (a sponsorship initiative undertaken by Mrs Steyn).

The lesson was introduced with an activity that required learners to colour in a worksheet that had faces drawn on it. Mrs Steyn instructed learners to 'colour in one of the faces that you think represents you today'. This was a way for her to be in touch with learners' emotions and to link this real-life experience to new knowledge. An attempt was then made by Mrs Steyn to link the new learning to the relevant previous knowledge of learners by referring to a past assembly talk. The assembly talk used the analogy of a suitcase for trying to carry someone's burden. The question was posed to learners: What do you think carries us through hard times? Learners responded 'Madam you love us all. Love is what carries us through'. Mrs Steyn then shared some snippets of her life with learners and concluded this section with the statement 'We are all angels with one wing and need each other to fly'.

Learners were then requested to take out the Valued Citizenship book and complete the relevant activities on the topic 'Emotions and Love' in groups of five. Each group was assigned a hypothetical case study based on the topic. Energetic, enthusiastic and stimulating group discussions ensued. Each group was required to provide feedback. Groups offered different reasons and different solutions. For example:

Mrs Steyn: Okay class, let's see what you have discovered from your story. I am going to ask the group leader of each group to provide feedback.

Ayesha (group 1): Mam, we think it is about accepting others.

Mrs Steyn: Can you tell me why your group thinks this?

Ayesha: Because if we don't accept each other then we cannot love each other.

Tim (group 2): We thought it is about the love and tolerance.

Mrs Steyn: Why do you say this?

Tim: Because mam, we must learn to live together then there will be no hatred.

Lindiwe (group 3): Our group thinks its all about misunderstandings. We need to learn to accept people who are different from us.

Mrs Steyn: How will this help us?

Lindiwe: We will then stop fighting and will all be happy.

Positive feedback was provided to learners all the time. Mrs Steyn constantly motivated learners and encouraged learner participation in the form of critical inquiry and reflective engagement. Many 'why' questions were posed. Given the nature of the topic Mrs Steyn reacted to the the collective feedback in the following manner: 'To be different is not wrong, you are entitled to your opinion'. She reassured learners whose answers she had not written on the chalkboard that it was not because their answers were wrong or unimportant, it was only because they overlapped with what had already been mentioned by others. This could be analysed as a way of making all learners feel 
that they have a contribution to make and that their opinions are valued. Learners were thus encouraged to put their views forward as a result of this reassurance. The lesson was consolidated with discussions about love, misunderstanding, acceptance, tolerance, negotiation and communication.

So class what did we learn about emotions and love today? We learnt that we need to accept and tolerate each other, no matter how different we are. We also learnt that if we do not communicate with each other there will be misunderstandings. We also learnt that we need to negotiate with each other by talking to each other. If we can do all this then there will be love and happiness. (Mrs Steyn)

Mrs Steyn aptly related the outcomes of the lesson to the real-life experiences of learners and to the social context. She shared snippets of her own experiences and allowed learners to see that she too had human flaws. In encouraging critical inquiry she referred to an occurence that many learners were exposed to on a daily basis, to stress the importance of learning: 'Don't end up like the beggars holding placards at the robots, take charge of your life by learning'.

\section{ANALYSIS AND DISCUSSION OF FINDINGS}

\section{Dismantling polarised thinking and shattering polite silences}

The first step towards practising a pedagogy of compassion might be for the teacher to dismantle polarised thinking and to shatter the polite silence in post-apartheid classrooms. Elbaz-Luwisch, $(2009,174)$ claims that key points in teaching in a postconflict situation are the need for flexibility and the ability of the teacher to continually re-evaluate his or her own pedagogy and the realisation that one has to listen to one's learners all the time. Mrs Steyn had taken the first step to disrupting received knowledge by making a paradigm shift which dismantled polarised thinking on so many levels and shattered the polite silence in post-apartheid classrooms. First, gender bias: 'Typical man, gives the banana to the woman to peel. Doesn't your father help in the kitchen? Please take that banana back and make sure you peel it'. Although this could be viewed as a cultural issue that is being viewed ethnocentrically by the teacher, it does however provide the teacher with an opportunity to engage with gender bias and the empowerment of females. It also provided the opportunity for learners who are not from an ethnocentric background to reflect on questions of power dynamics and the roles of males and females in their respective cultures. We are aware that in some cultures the man's place is not in the kitchen. Pedagogic dissonance happens when one's stereotypes are shattered and one experiences a sense of discomfort (Foucault 1994). This does not happen overnight. 'One incident of pedagogic dissonance does not of course lead to personal change, but it can begin to erode sure knowledge' (Jansen 2009, 154). It would seem that Mrs Steyn confronted these feelings by challenging issues head on. Given the time constraints of this lesson it is possible that this issue could have been addressed by 
Mrs Steyn in a follow-up lesson. Second, class differences and race issues in the 'swop back please' incident. Mrs Steyn was not only alert to race issues in this incident but she also took time to dismantle polarised thinking and shatter polite silences by explaining to Pieter and the rest of the class why his actions were problematic, and in this way tried to unlearn racism.

She saw the beauty and wealth of affirming diversity and felt personally enriched by adopting an inclusive and asset-based approach in her teaching. Diversity was affirmed in this classroom not only in terms of first order changes, i.e. changes in learner population, the celebratory approach to diversity, posters on classroom walls etc., but in terms of second order changes, i.e. changes in curriculum and changes in the visible symbols associated with the dominant racial culture and history of the school.

We take turns to greet each other at least once every two weeks in somebody's mother tongue. We share funny cultural stories. We share what good manners in one culture could be seen as bad manners in another. We share cultural songs and dances. My children teach me and the rest of the class three words of a different language every day.

Language is an essential part of and is intrinsically linked to peoples' ways of life, culture and identities. Language embodies many values and concepts and contains peoples' histories and development. Language is a fundamental marker of peoples' distinctiveness and cohesiveness as people. Valuing the languages of students is a good practice as it is integral to affirming and maintaining their wellbeing, self-esteem and their strong sense of identity.

Our language is like a pearl inside a shell. The shell is like the people that carry the language. If our language is taken away, then that would be like a pearl that is gone. We would be like an empty oyster shell. (Yurranydjil 2012)

The teacher should not only be an expert on the subject knowledge that is used in the classroom but the teacher and learners should also share each other's knowledge and this in turn shifts power in the classroom. Kanpol $(1994,51)$ develops this point when he argues that the teacher learns about student cultures and students become authorities on their own cultures when critical teaching and learning is practised in classrooms. In this way relationships are created where teachers and learners strive to understand differences and eradicate gender, race and class stereotypes.

The importance of hope that Jansen and Freire refer to is achievable in praxis. It is insufficient to just pronounce hope, it should be acted upon. This is clearly evident in the manner in which Mrs Steyn responded to the feedback provided by the different groups in the lesson on 'Emotions and Love'.

In the abovementioned ways Mrs Steyn created opportunities for pedagogic dissonance by thinking about her thinking alone and with others (Murphy \& Gallagher 2009,163 ). She adopted an 'epistemology of empathy' as suggested by Jansen (MaodzwaTaruvinga \& Cross 2012, 148) and an 'epistemology of compassion' (Vandeyar 2013; 
2016) that takes seriously experiences of both victims and the perpetrators of apartheid (including their descendants) and endorsed a pedagogy of compassion, which clearly illustrated that teaching is not only a cognitive act (Darder 2002, 99) but a class act of human compassion (Vandeyar 2013).

\section{Teaching a class act of human compassion}

Mrs Steyn seemed to possess the attributes of a progressive teacher and a transformative intellectual, namely, humility, love, courage, tolerance, decisiveness, security, patience and the joy of living (Freire 1998, 40-42). Learning was not only about the content but also about the relationship that she forged between herself, the learner and the learning experience. She was open to the idea that she may not have all the answers as evident from her comment 'To be different is not wrong, you are entitled to your opinion'. Sanzerbacher $(1991,109)$ interprets Freire's view on knowledge construction to mean that all knowledge is mediated and no one has the truth. The teacher and learner together construct knowledge; together they name the world (Sanzerbacher 1991, 109). Learners in Mrs Steyn's class were actively involved in learning and developing their own knowledge with the guidance of the teacher. She constantly motivated learners and encouraged learner participation in the form of critical inquiry and reflective engagement. Many 'why' questions were posed. As Shor $(1992,85)$ notes, 'an empowering teacher does not talk knowledge at students but talks with them'.

Relations with students in Mrs Steyn's class were kept fluid and equitable. Students were encouraged to learn collaboratively, to teach each other and be responsible for each other's learning (Ladson-Billings 1995, 163). Although Mrs Steyn had to adhere to national curriculum guidelines, she was not dependant on textbooks to decide what and how to teach. Her lessons were relevant to the learner's life-world and social context. In encouraging critical inquiry she referred to an occurence that many learners were exposed to on a daily basis, to stress the importance of learning: 'Don't end up like the beggars holding placards at the robots, take charge of your life by learning'. Learners were empowered to take responsibility for their own learning by applying critical thought. Critical thinking skills that are developed by the learner become life skills. These skills will be crucial in enabling learners to transform their world after they have left school. This is why Semali $(2000,7)$ writes that it is a lack of critical pedagogy in schools that creates passive citizens. This implies that the teacher should also have the courage to change and adapt and in this way be a lifelong learner and a participant in an evolving critical pedagogy. The fearless teacher challenges her own fears and has the moral courage to serve the interests of democratic action (Darder 2002, 48). In this way teachers and their students become 'transformative intellectuals'. 


\section{CONCLUSION}

Instead of arriving at a single truth to inform pedagogy, we should rather work towards a 'fusion of horizons' (Elliot 2005) through a form of consensus-making in order to bring together different views and notions of worthwhile change. In this paper we brought together the attributes that define a progressive teacher and a transformative intellectual (Freire 1998) and the three elements of post-conflict pedagogy (Jansen 2009) to propose a 'pedagogy of compassion'. Teachers need to assume the role of transformative intellectuals, rather than be alienated by the current educational dispensation, if they want to cause meaningful educational change. Freire $(1970,84)$ proposes that for teachers 'looking at the past must only be a means of understanding more clearly what and who they are so that they can more wisely build the future'. The new teacher thus envisaged needs not only to be able to raise the critical consciousness of learners but to adopt an 'epistemology of compassion' (Vandeyar 2016) in order to enable learners to become active critical citizens, imbued with a sense of common humanity and compassion. Taking up the role of transformative intellectuals may challenge the very premise of teachers' identities and practices, but by empowering the learner to exert influence on their world the teacher is in turn also changed and empowered. We therefore argue a case for a 'Pedagogy of Compassion' to effect meaningful educational change in postapartheid South Africa.

\section{REFERENCES}

Abrahams, F. 2005. The application of critical pedagogy to music teaching and learning: A literature review. Application of Research in Music Education 23(2): 12-22.

Boler, M. and M. Zembylas. 2003. Discomforting truths: The emotional terrain of understanding difference. In Pedagogies of difference. Edited by P. Trifonas. New York: Routledge.

Clandinin, D.J. and F.M. Connelly. 2000. Narrative inquiry: Experience and story in qualitative research. San Franciso: Jossey-Bass.

Darder, A. 2002. Reinventing Paulo Freire: A pedagogy of love. Cambridge: Westview Press.

Elbaz-Luwisch, F. 2009. The uses of conflict in the pedagogy of teacher education. Perspectives in Education 27(2): 169-176.

Elliot, J. 2005. Becoming critical: The failure to connect. Educational Action Research 13(4): 359373.

Elliot, J. 1968. Blues eyes/brown eyes. Retrieved from: http:/www.trainingabc.com/The-CompleteBlue-Eyed-with-Jane-Elliott-p-17481.html (accessed 15 June 2016).

Ellsworth, E. 1989. Why doesn't this feel empowering? Working through the repressive myths of critical pedagogy. Harvard Educational Review 59: 297-324.

Fien, J. 1993. Education for sustainable living: An international perspective on environmental education. Southern African Journal of Environmental Education 13: 13-20. 
Foucault, M. 1994. For an ethic of discomfort. In Essential works of Foucault. Vol. 3. Edited by J.D. Faubion, 443-448. New York: The New Press.

Fredericks, I. 2013. Teacher suspended for money blunders. Cape Argus, 23 September.

Freire, A.M.A. and D. Macedo, eds. 1998. The Paulo Freire reader. New York: Continuum.

Freire, P. 1970. Pedagogy of the oppressed. New York: Seabury.

Freire, P. 1985. The politics of education: Culture, power and liberation. Massachusetts: Bergin \& Garvey.

Freire, P. 1992. Pedagogy of hope: Reliving pedagogy of the oppressed. London: Continuum.

Freire, P. 1998. Teachers as cultural workers: Letters to those who dare to teach. Colorado: Westview.

Giroux, H.A. 1983. Theory and resistance in education: A pedagogy for the opposition. Massachusetts: Bergin \& Garvey.

Gravett, S. 2001. Adult learning: Designing and implementing learning events. A dialogic approach. Pretoria: Van Schaik.

Guba, E.G. and Y.S. Lincoln. 1994. Competing paradigms in qualitative research. In Handbook of qualitative research. Edited by N.K. Denzin and Y.S. Lincoln, 105-117. Thousand Oaks: Sage.

Habermas, J. 1981. The theory of communicative action. London: Heinemann.

Hadfield, M. 2012. Becoming critical again: Reconnecting critical social theory with the practice of action research. Educational Action Research 20(4): 571-585.

Jansen, J.D. 2009. On the clash of martyrological memories. Perspectives in Education 27(2): $147-157$.

Jansen, J.D. 2012. Education crisis a threat to democracy. News24, 22 November. Retrieved from: athttp://news24.com (accessed 3 February 2014).

Kanpol, B. 1994. Critical pedagogy: An introduction. Westport: Bergin \& Garvey.

Keet, A., D. Zinn and K. Porteurs. 2009. Mutual vulnerability: A key principle in a humanising pedagogy in post-conflict societies. Perspectives in Education 27(2): 109-119.

Khoza, A. 2016. Burning schools undermines right to basic education. News24, 5 May. Retrieved from: http:/www.news24.com/SouthAfrica/News/burning-schools-undermines-right-to-basiceducation-sahrc-20160505 (accessed 23 November 2016).

Ladson-Billings, G. 1995. But that's just good teaching! The case for culturally relevant pedagogy. Theory into Practice 34(3): 159-165.

Maddock, T. 1999. The nature and limits of critical theory in education. Educational Philosophy and Theory 31(1): 43-61.

Makhubu, N. 2013. Gang war at city school. Pretoria News, 11 October. Retrieved from: http://www. pretoria-news.co.za/gang-war-at-pretoria-school/ (accessed 3 February 2016).

Maodzwa-Taruvinga, M. and M. Cross. 2012. Jonathan Jansen and the curriculum debate in South Africa: An essay review of Jansen's writings between 1999-2009. Curriculum Inquiry 42(1): $126-152$.

Mayring, P. 2000. Qualitative content analysis. Forum for Qualitative Research: Qualitative Social Research 1(2). Retrieved from: http:/qualitativeresearch. net/fqs/fqs-e/2-00inhalt-e.htm (accessed 26 March 2010). 
Murphy, K. and T. Gallagher, 2009. Reconstruction after violence: How teachers and schools can deal with the legacy of the past. Perspectives in Education 27(2): 158-168.

OECD. 2011. Perspectives on global development 2012: Social cohesion in a shifting world. Paris: OECD. DOI: http://dx.doi.org/10.1787/persp_glob_dev-2012-en (accessed 25 June 2015).

Otto, J. 2013. School teacher charged with rape. Cape Argus, 10 October.

Palmer, J.A. 2001. Fifty modern thinkers on education: from Piaget to the present day. London: Routledge.

Samoff, J. 2008. Foreword. Bantu education. People's education. Outcomes-based education: Whither education in South Africa. In Educational change in South Africa: Reflections on local realities, practices, and reforms. Edited by E. Weber, 113-127. Netherlands: Sense Publishers.

Sandelowski, M. 2000. Focus on research methods. Whatever happened to qualitative description? Research in Nursing and Health 23: 334-340.

Sanzerbacher, R. 1991. The conflict between technology and the environment. College Teaching 39(93): 109-112.

Seleka, N. 2013. Three pupils held over unlicensed firearm: Police chased suspects from school. Sowetan, 14 October.

Semali, L.M. 2000. Literacy in multimedia America: Integrating media education across the curriculum. New York: Falmer Press.

Shor, I. 1992. Empowering education: Critical teaching for social change. Chicago: University of Chicago Press.

Tubbs, N. 1996. Becoming critical of critical theory in education. Educational Philosophy and Theory 28(2): 42-54.

Vandeyar, S. 2013. Teaching a class act of human compassion. Mediterranean Journal of Social Sciences 5(8): 57-61.

Vandeyar, S. 2016. The teacher as an agent of meaningful educational change. Educational Sciences: Theory and Practice (in press).

Yin, R.K. 2013. Case study research: Design and methods. 5th edition. California: Sage.

Yurranydjil, D.G. 2012. Language learning in indigenous communities. Report to Commonwealth Government of Australia, September.

Zembylas, M. 2010. Teachers' emotional experiences of growing diversity and multiculturalism in schools and the prospects of an ethic of discomfort. Teachers and Teaching: Theory and Practice 16(6): 703-716. 